\title{
Institutional Change in Economic Geography
}

\author{
Harald Bathelt \& Johannes Glückler
}

\author{
Version Post-print/accepted manuscript \\ Citation Bathelt, H., \& Glückler, J. (2014). Institutional change in economic \\ (published version) geography. Progress in Human Geography, 38(3), 340-363. \\ Copyright / License \\ Publisher's Statement The version of record [Bathelt, H., \& Glückler, J. (2014). Institutional \\ change in economic geography. Progress in Human Geography, 38(3), 340- \\ 363.] is available online at: \\ http://phg.sagepub.com/content/38/3/340 \\ [doi: 10.1177/0309132513507823]
}

How to cite TSpace items

Always cite the published version, so the author(s) will receive recognition through services that track citation counts, e.g. Scopus. If you need to cite the page number of the TSpace version (original manuscript or accepted manuscript) because you cannot access the published version, then cite the TSpace version in addition to the published version using the permanent URI (handle) found on the record page. 


\title{
Institutional change in economic geography
}

\author{
Harald Bathelt \\ University of Toronto, Department of Political Science and \\ Department of Geography \& Program in Planning, Sidney Smith Hall, \\ 100 St. George Street, Toronto ON M5S 3G3, Canada, \\ e-mail: harald.bathelt@utoronto.ca, URL: http://www.harald-bathelt.com \\ and \\ Johannes Glückler \\ University of Heidelberg, Institute of Geography, \\ Berliner Str. 48, 69120 Heidelberg, Germany, \\ e-mail: glueckler@uni-hd.de, URL: http://www.economic-geography.uni-hd.de
}

\begin{abstract}
This paper develops a rigorous concept of institutions to investigate the interrelationships between institutional and economic change from the perspective of economic geography. We view institutions neither as behavioural regularities nor as organisations or rules, but conceive institutions as stabilisations of mutual expectations and correlated interaction. The paper discusses how economic interaction in space is shaped by existing institutions, how this leads to economic decisions and new rounds of action, and how their intended and untended consequences impact or enact new/existing institutions. The paper explores three modes of institutional change - hysteresis, emergent change, and institutional entrepreneurship.
\end{abstract}

Keywords. Institutions, institutional change, institutional entrepreneurship, institutional hysteresis, relational economic geography, technological change

JEL classifications. O10, O30, R11, Z13 
Acknowledgements. This paper is based on a presentation at the Third Global Conference on Economic Geography 'Space, Economy and Environment', 28 June - 2 July 2011, COEX, Seoul, Korea. We are grateful to the participants for stimulating comments and would like to thank three anonymous Reviewers and, especially, Susan Roberts for their engaging and insightful suggestions that have inspired our revisions.

Funding acknowledgement. Parts of this paper were funded by the University of Heidelberg and the Canada Research Chair in Innovation \& Governance at the University of Toronto. 


\section{Introduction}

A relational perspective in economic geography focuses on the analysis of economic practices at the micro level - be it related to specific actors or the social relations between them (Bathelt and Glückler 2003; 2011; Yeung 2005). Such an analysis necessarily leads to a number of important questions regarding the relationship between structure and agency, and the role of macroeconomic and societal conditions. It also raises questions about the types of methods that may be most usefully employed in a relational approach to the study of economic development. Economic action as social action is not unconditional. It is guided by, enabled through, and constraint by 'institutions' in the sense of accepted, existing patterns of interaction - be they related to some sort of rules and regulations or to conventions of social and economic life.

However, a closer look through the literature in economic geography and related disciplines reveals that institutions are often vaguely defined, refer to different meanings, or almost become a 'black box' to relate to otherwise unexplained influences in economic development. This is highly problematic because it establishes substantial hurdles when trying to integrate and interpret findings from different strands of research to advance our knowledge in the field. Such interpretation even becomes an impossibility when institutions are almost arbitrarily used with varying meanings. A good example to illustrate this is the literature on innovation systems that, although emphasizing the interrelationships between institutions and innovations, does not provide a generally accepted understanding of institutions. While Nelson (1993), for instance, appears to understand institutions as the legislation and organisations of education, training, funding, and research frameworks that differ at a national level and thus create national innovation systems, Edquist and Johnson (1997: 43) view institutions as "the things, that pattern behaviour, e.g., routines, norms, shared expectations, morals, etc." While the one account 
emphasizes organisations as institutions, the other focuses on the role of laws, rules, regulations, etc. (see, also, North 1990; Gertler 2010). Both perspectives, although quite different in character, tend to view institutions as structures that shape and direct action. Comparing institutions as social technologies with physical technologies, Nelson and Nelson (2002: 269) suggest that they are like "a paved road across a swamp ... Without a road, getting across would be impossible, or at least much harder."

Another perspective can be found in Lundvall and Maskell's (2000) analysis of national innovation systems. Within this analysis, the authors adopt a perspective that comes close to the understanding of institutions suggested in this paper, where institutions are linked explicitly to practices of repeated interaction, instead of viewing them independent from economic action. For instance, Lundvall and Maskell (2000: 362) link institutions to the development of trust, to the way of how authority is expressed, and with the way "how things are done" and "how learning takes place" in different national contexts. In this understanding, institutions develop from and co-evolve with solving specific problems in production through processes of interactive learning (see, also, Lundvall 1992; Archibugi et al. 1999). Overall, the sometimes confusing use of the term 'institution' calls for clarification.

The agenda of this paper is therefore to generate an explicit conceptualisation of institutions and institutional change in the context of relational economic geography that integrates approaches from different fields of the social sciences. We view institutions neither as organisations nor as rules or simple regularities, but conceive institutions as stabilisations of mutual expectations and correlated interaction. In economic geography, institutions are often not explicitly defined and, frequently, the role of institutions appears to be hidden behind spatial patterns or assumed 'spatial laws'. Although institutions have been discussed numerous times within the discipline in recent years (e.g., Amin 1999; Storper 2004; Rodríguez-Pose and Storper 
2006; Farole, Rodríguez-Pose, and Storper 2010), calls for an institutional perspective have not led to more clarity in research practice. ${ }^{1}$

In response to this, we aim to develop a consistent perspective of how institutions can be usefully conceptualised in investigations of economic action and interaction in local/regional and cross-regional/global context without conceiving them as a-priori spatial constructions. While our conceptualisation draws from Giddens' (1984) work to overcome the duality between structure and agency, our arguments are also related to findings from actor-network theory (Latour 1986), the theory of social systems (Luhmann 1984), and Foucault's (1980a; 1980b) work on the micro technologies of relations of power that concentrate on the flows of action and communication. ${ }^{2}$ The relational approach focuses on the roles of agents and organisations, the economic practices and relationships in which they engage, and the resulting social institutions and their dynamics at different spatial and non-spatial scales. With respect to this understanding, it is neither our intention to engage in a debate about scales (see Ettlinger 2011), nor to disregard literature that applies a different understanding of institutions. Rather, we wish to emphasize that we need to have a clear, explicit conceptualisation of institutions in order to make sense of the diverse literature and draw appropriate conclusions from it. While insisting on the need for consistency in each approach, such conceptualisation enables us to translate between different strands of

\footnotetext{
${ }^{1}$ Boschma and Frenken (2009), for instance, while favouring a structural understanding apply a territorial perspective of institutions as durable structures that are specific to territories (p. 152), including markets, property rights and the judicial system (p. 155) without clarifying why they restrict themselves to such a narrow interpretation.

${ }^{2}$ In contrast to rigid interpretations of the theory of social systems and actor-network theory, which do not need to conceptualise individual agents and institutions, because their explanations are completely focused on the linkages and communication between agents, our approach builds upon individual and collective actors and their actions. In this sense, our analysis is inspired by Foucault's (1980a; 1980b) emphasis on micro processes and those agents that are bound together through them (Gordon 2000; Allen 2003).
} 
literature and link the respective approaches. Through this, we may be able to learn from various empirical investigations of how institutions provide the basis for and how they shape economic interaction, even if such studies build upon a different view of institutions (e.g., Gertler 2004; Hargadon and Douglas 2001).

This paper presents a critical review that discusses the role of economic agents, their rationalities and strategies, and how these lead to specific practices of economic interaction. Our purpose is not only to link agents with economic practices, but also to conceptualise institutions as important mediators between the micro and macro, as well as local and global scales of analysis. In particular, we discuss how institutional change or hysteresis can occur in the context of technological change. We investigate how economic interaction in space is shaped by existing institutions, how this leads to economic decisions and new rounds of action, and how intended and unintended consequences support institutional adaptations that impact future motivations and action. As such, we conceptualise a reflexive rather than a dualistic relationship between economic action and institutional settings. Based on a relational perspective, we describe how institutions emerge in a contextual, path-dependent, yet contingent way. Once in place, however, powerful economies support institutional hysteresis establishing structures of relationships that resist sudden and radical changes. We discuss the tensions between institutions and innovations to develop a relational perspective of how institutions can guide technological change while minimising the risk of lock-in processes.

This paper is organised as follows: Section 2 discusses the role of economic agency, the type of agents included, and their rationalities. It then defines a concept of institutions in contrast to simple behavioural regularities, rules, and organisations. Since technological change is deeply interdependent with the social institutions that inform collective reasoning, action, and legitimation, the discussion that follows focuses on the stability, flexibility, and change of 
institutions. As 'strong' technologies may sometimes fail against 'inferior' technologies, social institutions play a crucial role in facilitating or hampering technological innovation. Similarly, 'bad' institutions may resist or impede the emergence and diffusion of 'good' institutions. This leads us to an analysis of how institutions allow for and guide technological change. We focus on three qualities of institutional dynamics, namely how institutions (i) persist, (ii) emerge, and (iii) how they are purposively generated. Section 3 discusses mechanisms of institutional hysteresis and points to institutional constraints on economic development and the emergence of new institutions. Section 4 reviews the relationships between agency and structure in the light of structuration theory and suggests institutions as mediators between micro and macro levels of analysis. Section 5 elaborates on the paradox of embedded action and discusses institutional entrepreneurship as a field of analysis of the purposive action dedicated to creating and implementing new institutions in emerging organisational fields or markets. Section 6 concludes our analysis with implications and future questions for economic geography.

\section{Agency, institutions, and the problem of technological change}

\subsection{Agency and rationalities ${ }^{3}$}

When conceptualising the role of institutions in economic geography, a natural starting point is to think about the incentives and constraints that impact economic action and interaction in spatial perspective. Although existing structures, such as locational distributions of suppliers, customers, and resources, as well as material infrastructures, define the basic framework for any action, agents - in the first place - act according to certain goals, purposes, and rationalities. An important question when analysing economic action is, of course, which actors should be

\footnotetext{
${ }^{3}$ See Bathelt (2006: 228f.).
} 
included in our research and how. At the core of the relational perspective are individuals that make economic decisions and interact with others in research, production, and transaction processes, i.e., workers, managers, consumers, and politicians. Their activities are assumed to be generally purposeful, although they may have unintended consequences (e.g., Hudson 2004). It is questionable, however, whether it is possible to limit an analysis to these individual actors. In economic contexts, there are important collective actors, such as firms, governmental bodies, and other organisations, which need to be considered. These types of collective actors differ from individuals and cannot be reduced to them (Oinas 2006; also Maskell 2001). Firms, for instance, operate differently from individuals as managers and workers may perform particular roles in their business life, when engaging in complex processes of negotiation and decision-making. Firms are also organised around structures and procedures that are (to some degree) independent from the individual agents who operate inside these organisations (Lawson and Lorenz 1999; Nelson 1995).

The conceptual foundations of action in this approach are based on an institutional perspective (Amin 1999), in which the goals and preferences of economic action are not predetermined by the assumption that actors are rational, utility-maximising individuals (Hodgson 2003). In reality, individual and collective agents are embedded in structures of social relations that influence their decisions and actions (Granovetter 1985). They are, for instance, involved in specialised producer-user networks and cannot easily change their transaction partners and production programs from one day to the other (Grabher 1993).

Furthermore, there are various rationalities at work, which yield differences in economic performance (Amin 1999). Agents may choose between an instrumentalist rationality (which focuses on reactive problem-solving in a stable environment), a procedural rationality (which breaks problems down and solves them in a stepwise manner), or a recursive rationality (which 
tries to anticipate changes and to actively shape the environment). The predominance of a particular rationality depends on the agents' contexts and experiences. ${ }^{4}$ At the same time, "individuals engage in multiple networks associated with different rationalities, and these different networks ... [can be] overlapping networks" (Ettlinger 2003: 161). Therefore, economic relations also depend on those social, cultural, and political rationalities that affect economic strategies and decision-making. As opposed to traditional approaches, a relational conception is capable of integrating multiple rationalities and complex contexts of economic action. Multiplex relations link people in many different ways as neighbours, friends, and business partners (Uzzi 1997). They provide a means of engaging resources from one type of relationship to another, and of transferring institution-based trust into inter-personal trust and vice versa. Based on such dynamic processes, economic, social, and cultural relations may define a creative 'field' that stimulates entrepreneurship, learning, and innovation, and leads to positive spatial externalities, if concentrated in physical spaces such as regional agglomerations (Scott 2004). However, creativity and innovation may also emerge from non-localised institutional fields, such as those related to virtual communities (Grabher and Ibert 2013), and are not bound to territorial scales perse.

In some of the literature on economic networks and the 'cultural turn', there is a tendency to overstate the social dimension of economic interaction while neglecting economic considerations in explanations of such action. At least implicitly, networks are sometimes portrayed as if they were ultimately democratic, consisting of altruistic agents engaging in 'friendly' exchange relationships (critically, Sayer 2001). Without denying the importance of the socio-institutional

\footnotetext{
${ }^{4}$ The argument here is that it is important to include both the individual motivations of economic agents and the socio-institutional contexts of their actor-networks, instead of primarily focusing on the latter relationships as suggested, for instance, by Yeung (2005).
} 
context, our conceptualisation does not ignore the fact that economic agents are generally interested in enhancing their personal wealth (Taylor 2004). Indeed, this is a key driver of economic action and interaction. Competition, rivalry, market interaction, and 'market-making' are, thus, important aspects that shape economic action in a relational perspective.

In short, the relational approach suggests that economic agents act according to economic and non-economic goals and strategies (Massey 2004; Ettlinger 2004). The results of such deliberate action include intended and unplanned spatial outcomes which, in turn, impact the next round of decisions (Werlen 1995; Bathelt and Glückler 2011). To understand the underlying processes and rationalities of economic action, it is important to adopt a micro perspective that emphasizes the contextual, path-dependent, and contingent nature of economic action and interaction.

\subsection{Toward a concept of institutions}

Economic action is not atomistic but relational. Individual preferences, norms, values, ethics, tastes, styles, needs, and objectives emerge from and are co-constituted through the social embedding of economic interaction. Economic actors are not isolated beings who carry out atomistic behavioural scripts; rather, they are embedded in a social environment that constitutes meaning through repeated interaction. ${ }^{5}$ Such a concept of relational action has three implications (Bathelt and Glückler 2003; 2011): (i) contextuality, related to situated practice and reflexive, transformative action, (ii) path dependence, which is a matter of institutionalisation and imprinting, and (iii) contingency, associated with serendipity, historical points of inflection, and purposive action toward institutional change. Relational action is thus an expression of a perspective where real interaction is informed by historical patterns of mutual expectations (path-

\footnotetext{
${ }^{5}$ This approach draws on a similar understanding and agenda as the practice approach (Jones and Murphy 2010).
} 
dependence) and where, at the same time, contextual interaction contributes to the transformation of these patterns based on the principle of contingency. The interplay between experiential action and patterns of instituted expectations drives a recursive process of correlated interactions and transformative institutionalisation. ${ }^{6}$

To illustrate this, we provide two examples below that help us understand the potential confusion in terminology regarding institutions, organisations, and rules and other regularities. Both examples are phrased as hypothetical problems but relate to empirical cases discussed in the literature:

Example 1 assumes that the Fordist crisis leads to increasing unemployment as integrated mass producing firms struggle to remain competitive and, as a result, release workers. In a region, that is impacted by this crisis, regional policy makers and banks come up with a policy that provides incentives for new ventures in the form of start-up money in order to try to reduce the negative effects of the crisis. However, rather than stimulating new start-ups in a different industry, this policy causes regional dis-integration as former employees acquire machinery and establish their own businesses. They create close inter-firm linkages with their former employers and extend these linkages to other firms in the region, thus contributing to the development of

\footnotetext{
${ }^{6}$ This relational perspective bears many similarities with Foucault's (1980a; 1980b) writings of relations of power. As discussed in earlier work (Bathelt and Glückler 2011, Chs. 4 and 5; 2012, Ch. 8), power can be conceptualised as a relational resource in a similarly 'positive, productive' way, as suggested by Foucault (see, Allen 2003). In particular, a Foucauldian perspective suggests viewing power as an enabling and generating force through the involvement of agents in joint action, as opposed to restricting it to a 'negative' view of power as the mechanism of coercion of economic practice (Foucault 1980a; 1980b: 142). The Foucauldian approach further suggests to engage in micro-level analysis, as a starting point for wider explanation that includes the roles of agents and investigates seeming regularities strictly in the specific social and historical contexts within which they occur, as well as the reflexive relationship between object and subject (Foucault 1980a; 2000). We are very grateful to one of the Reviewers who suggested to us in a series of insightful comments to take this into consideration.
} 
wider regional networks, based on and contributing to the development of trust, while, at the same time, stimulating more competition. This process is closely related to some of the restructuring processes that were characteristic in the Third Italy as analysed by Amin and Thrift (1992). Neither the governments/banks, nor the rules/policies were in this case institutions. Instead, there were a number of stable social practices that developed simultaneously, which we refer to as institutions. For instance, this policy led to the establishment of trust-based inter-firm interaction. It also stimulated the formation of competition patterns. Furthermore, it resulted in start-up practices associated with spinning-off parts of production processes and stimulating vertical dis-integration. Empirical research in the context of industrial districts in Italy and France has illustrated how such 'social practice institutions' (Glückler 2005) emerge from everyday practice. In a case study of a Lyon-based manufacturing district, Lorenz (1999: 308) identified the informal basis of the 'moral contract' that entrepreneurs develop as an important orientation for non-contractual inter-firm collaboration. These institutions build upon mutually shared and legitimate expectations that are articulated, for instance, through the symbolic interaction of a handshake which "is worth more than a piece of paper with writing on it" (interview quote from Farrell and Knight 2003: 556). The specific economic advantage of such institutionalisation rests on the ability of actors to adapt their interaction to situations which are subject to unanticipated contingencies that could not possibly be ruled out contractually.

Example 2 assumes that the government in a country establishes new social security legislation and corresponding organisations with the intention to reduce the influence of unions and increase worker loyalty to the state. Over time, however, the state regime changes and the new social security system now operates in a different context and has a completely different impact under different economic conditions. In the new situation, the social security regulations generate employment security, stabilise the positions of unions, and establish a basis for on-going 
interaction between the agents. This, in turn, provides the preconditions for robust employment relations, which enable incremental learning processes and cumulative innovation. This example draws on the historical case of the establishment of the welfare state under Bismarck in 19th century Germany, which was meant to strengthen worker loyalty to the monarchy and, in turn, weaken the upcoming union movements (Thelen 2004). In the post-World War II development under Germany's new democracy, these same social security regulations, however, had a very different effect. As described in Katzenstein's (1987) account on the so-called 'semi-sovereign state', the social security system generated the preconditions for long-term employment and collaborative union-employer relationships that greatly supported economic development. The introduction of the welfare state supported a different set of institutions with respect to labour relations. Instead of stabilizing a hierarchical capital-labour nexus based on worker loyalty without an active role of the unions, inclusive capital-labour relations were generated with longterm employment relations, comprehensive co-determination, and on-going involvement and mediation of unions. This example again shows that it is necessary to distinguish, on the one hand, between organisations as actors in pursuit of specific goals, rules as prescriptions of legitimate or even legal behaviour, and, on the other hand, the resulting stabilised interaction practices. These stabilised practices were the institutions that resulted from the new regulations.

Both examples illustrate that institutions are related to rules and regulations (or may develop from norms), but that their characteristics can be quite different because they are subject to processes of evaluation, implementation, and application. In other words, they have to be put into economic practice. The examples also show how institutions can change over time while relying on the same formal basis of laws and regulations. Further, they can develop at different spatial levels (although they may also develop in non-spatial contexts, for instance driven by technology chains). It is important to note that, depending on the institutional understanding, different 
conclusions could be drawn from the same empirical reality - leading to different policy conclusions. For instance, an interpretation of institutions as rules in Thelen's (2004) example of the social security system in Germany might come to the conclusion that 'institutions' have proven to be quite persistent in economic history, while our understanding leads to the conclusions that 'institutions', in the sense of stabilised patterns of interaction, have fundamentally changed - even though the basic rules and regulations upon which they are based have remained the same.

These examples suggest that a first step toward a definition of institutions may be to explicate what institutions are not. We depart from this negative definition because part of the conflation in the debate about institutions is the ambiguous use of the term, where some of the meanings clearly refer to distinct phenomena or structures. The following three social phenomena should in this context not be viewed as social institutions:

(i) Simple behavioural regularities. Social life is filled with repeated action where people adhere to perpetual customs, such as the sequence of exercises that an athlete repeats in warming up. As long as these simple regularities of individual behaviour do neither affect expectations for the actions of others, nor enforce sanctions against any deviation, these regularities are not social institutions (Esser 2000). Simple regularities only become institutions if they generate expectations, create patterns of interaction, and if they are supported by effective sanctions (Bathelt and Glückler 2012).

(ii) Organisations. Institutions are also not organisations or governmental bodies that have a certain form and can be clearly separated from their environment - be it through ownership ties or territories of competence. Organisations are sets of actors and resources targeted to pursue common objectives and, as such, can be viewed as collective actors. Institutions are the 
stabilisations or correlations of the interactions between individual or collective actors. ${ }^{7}$ They are thus associated with specific economic and social processes, not with specific outcomes or measurable characteristics.

(iii) Rules. Rules, laws, and regulations are codified prescriptions, they are 'not yet institutions'. Institutions are not like rules that can be written up and shared with others by means of reading and interpreting. In fact, rules and laws can be meaningless if common practices disregard or deviate from them without identifiable sanctions. Yet, institutions develop in relation to rules, in response to them, or even against them - they are shaped by the presence of rules, but in a rather contingent manner as illustrated in the previous two examples.

The exclusion of these phenomena turns our focus toward a positive definition of social institutions: We define institutions as forms of on-going and relatively stable patterns of social practice based on mutual expectations that owe their existence to either purposeful constitution or unintentional emergence (Hartfiel and Hillman 1982; Bathelt and Glückler 2011). Institutions are based on different kinds of overt or covert rules and may thus be formal (e.g., based on laws or regulations) or informal (e.g., based on norms or conventions) in nature. ${ }^{8}$ Institutions increase an actor's expectations about the likely responses of other actors and therefore create steadiness and consistency in social interaction (Glückler 2005; Bathelt 2006). However, since certain rules and

\footnotetext{
${ }^{7}$ When we refer to collectives of actors (i.e., firms), these are viewed as organisations, not as institutions. However, within these organisations, specific types of institutions may develop that can be referred to as routines.

${ }^{8}$ Although our argument does not focus on routines, it is necessary at this point to distinguish between institutions and routines, as routines are often emphasized in the context of technological change and evolutionary economics. We view routines as a subcategory of institutions, referring to intra-organisational stabilisations of social relations, or to stabilisations of interaction in close organisational contexts (Feldman and Pentland 2003). They have a distinct procedural character and are often discussed in the context of firms. Firm-based routines are constantly reproduced through on-going interaction within the organisation's hierarchy, secure control over the labour and production processes, and establish a kind of organisational memory (Nelson and Winter 1982).
} 
regulations may be applied differently in different contexts, they may lead to varying stabilisations of interaction and therefore create a certain variety of spatially-/temporally-specific institutions. Orlikowski (2000) demonstrates this in the case of a new professional software package that resulted in rather different corporate practices in its application and in the specific problems that were addressed. A relational understanding of institutions thus leads us to acknowledge institutional variety and opens grounds for a geographical approach to institutional change. In fact, when characterising typical institutions, such archetypes might be viewed as average representations of stabilised interaction patterns that may have a different form depending on the context. ${ }^{9}$

To move a step forward, we should emphasize that institutions are clearly not a-priori spatial constructions because they arise, in the first place, from specific social and technological realities, problems, or challenges in economic life. As such they are socio-economic in character, not spatial. ${ }^{10}$ However, since many institutions develop in relation to rules and regulations or to norms that have a territorial basis - and, thus, in relation to boundaries (e.g., the borders of the national state that issues new social security legislation or the regional context of conventions

\footnotetext{
${ }^{9}$ There are many aspects that could lead us to draw parallels with the work of Foucault. These include the distinction between laws, organisations, and relations of power (Foucault 1980a: 115f.), the need to analyse 'regimes of practices' (Foucault 2000: 225) in order to identify inter-situational repeated action, the focus on processes of reproduction instead of structures (Foucault 1980b), or the problems of deterministic macro-scale analyses. At the same time, however, we would like to exercise care in referring to the Foucauldian framework. First, Foucault's work makes little reference to technologies/innovation in the context of economic change. Second, Foucault uses the term 'institution' explicitly but in a less clearly defined way as power (e.g., Foucault 2000: 225), and often only in passing. It would open up a lot of questions to comprehensively use his arguments about relations of power to conceptualise institutions in our context, while neglecting his direct references to them.

${ }^{10}$ This becomes particularly clear in the literature on communities of practice and epistemic communities which shows how institutions are formed through a non-spatial logic (e.g., Wenger 1998; Wenger and Snyder 2000; Knorr Cetina 1999; Grabher and Ibert 2013).
} 
related to vertical dis-integration processes) - the resulting formal and informal institutions are related to this territorial basis. Although institutions may not have a spatial foundation per se and although the specific institutions that develop from repeated interaction depend on the specific context, we may often be able to observe spatial differences and specialisations of institutions in comparative studies between different local, regional, or national territories.

Having clarified our understanding of institutions, we proceed by applying this to the area of innovation and technological change in which institutions play a key role. While conventional approaches to innovation tend to assume that new technologies become established because they are inherently superior to existing technologies, the reality is less consistent with such functional claims, as certain technologies become widely adopted, whereas other equally efficient technologies fail to be accepted. The lessons that history tells us suggest an institutional, rather than a purely functional approach to the explanation of technological change. Obviously, institutions form an important element in the dynamics and directions of technological change and the focus on institutions may help us to distinguish between 'technologies as artefacts' (that may or may not be used) and 'technologies-in-practice' (suggesting that innovations may be applied in different ways) (Orlikowski 2000). In the following sections, we investigate the relationships between institutional and technological change pursuing three lines of arguments: problems of institutional hysteresis (Setterfield 1993), emergence of new institutions (e.g., Hall and Thelen 2009), and practices of institutional entrepreneurship (DiMaggio 1988).

\section{Institutional hysteresis}

Institutions play a critical role in economic interaction because they establish the basic conditions for information and knowledge exchange. Institutions can become a burden, however, if they are associated with rigid conditions that limit the perceptions and opportunities of economic actors. 
This is particularly problematic when institutions support inefficient economic or technological developments, and lead economic networks to rely on internal problem-solving and existing power hierarchies, instead of searching for best-practice solutions, for instance at a wider national and international level. Although lock-in situations can be a source of high economic returns over extended periods of time, they may lead to a negative 'catch 22' situation, or one in which better technological choices are ruled out (Martin and Sunley 2006). Although institutions are subject to on-going incremental adjustments, negative lock-in can trigger constellations that are hostile to institutional change (Hassink and Shin 2005), which can lead to a situation that has been referred to as institutional hysteresis (Setterfield 1993). While institutional hysteresis is different from lock-in, as it relates to the effects (or power) of institutions that persist even if the original conditions that caused their creation might have long disappeared, both can be interdependent and may stimulate one another. This raises a number of important questions regarding the potential problems that institutions create in terms of (i) processes of innovation and knowledge generation, (ii) the persistence of inefficient institutions in supporting practices that are suboptimal, disruptive, or unsustainable, and (iii) the creation of such institutions in the first place (Bathelt and Glückler 2011; 2012).

\subsection{Institutions versus innovations}

One important question that arises from the above discussion is related to the way in which institutions may inhibit innovation processes. In the context of strong institutions and power relationships associated with existing economic structures, it might be difficult to introduce new technologies to the market and become a successful innovator in the face of opposing or contrary social forces. Whereas (established) institutions, on the one hand, are strongly associated with stability and pre-existing structures, (new) innovations, on the other hand, propose and often 
require substantial changes of institutions toward new stabilisations of interaction. The potential problems that can arise in such situations have been well illustrated in the historical context of the introduction of the electrical light by Thomas Alva Edison (Hargadon and Douglas 2001). In the case of the electrical light, the oligopoly of the then dominating gas industry had created rigid institutions that prevented a shift toward the electrical light technology. This historical case exemplifies that innovative success is not necessarily a direct consequence of technological superiority (David 1985). Hargadon and Douglas (2001) argue that associative points have to be found in innovation processes to present the design of a new product in established interpretative contexts in order to increase an innovation's initial acceptance. To accommodate this, the design of an innovation needs to actively relate to existing institutions, while, at the same time, offering enough flexibility to indicate adaptability to new and changing market environments. As the case of the electrical light illustrates, innovations are more likely to succeed if they are introduced in the context of existing institutions. This provides legitimacy, but also generates incentives to modify these institutions. Edison, for instance, had the supply infrastructure for electrical light laid underground and used low-voltage light bulbs to make the new light appear in a form that was familiar to long-term gas light consumers.

\subsection{Persistence of inefficient institutions}

Although this speaks to institutional persistence, the question arises as to why conventions would persist even if they are clearly suboptimal or counterproductive to technological change. Setterfield (1993) identifies a number of possible explanations for this. Following a similar logic as in the classical prisoners' dilemma in economics, institutional inefficiencies might persist if they help to avoid conflicts regarding, for instance, the redistribution of resources or outcomes. Another reason for maintaining inefficient institutions involves the avoidance of economic 
sanctions. An industrial supplier, for instance, might choose to rely on outdated delivery systems in order to maintain relations with its major customers (see, also, Uzzi 1996). The potentially high cost of changing institutions is another factor that may help explain why institutional inefficiencies can persist. Indeed, given that institutions are often systematically interrelated, changes in one institutional domain might require extensive investments in other domains. The interrelatedness of institutions can thus inhibit changes in one institutional dimension, irrespective of others (Frankel 1955) - and eventually slow down or prohibit technological change.

Finally, the continued acceptance of an institution that has potentially negative economic or social consequences may even be a rational choice from an agent's perspective. This is a problem that has been discussed in the context of the socialisation of negative external effects in the economy. Marquis (2003) provides an illustrative example of the persistence of such institutions from a geographical perspective. He compared the development of networks of interlocking directorships in the largest U.S. cities, and demonstrated that the business networks of cities that were established prior to the advent of air travel technology were significantly more locally bound than the networks of younger cities. Despite the availability of modern travel technologies in the entire urban system, new corporate board positions in older cities were filled predominantly with local directors. The persistence of this routine in older communities illustrates the basic argument of imprinting theory (Stinchcombe 1965). According to this perspective, organisations adopt characteristics in response to the environmental conditions that exist during their period of foundation. These imprinted patterns are sustained over time, and persist even through periods of significant environmental change. Since the social technology of long-distance travel was not available before the introduction of air transport, business communities had to assign local directors to their corporate boards. These imprinted practices 
constituted a "locally legitimate template of action" (Marquis 2003: 656) or, in other words, a persistent and trans-contextual institution of board composition.

\subsection{Establishment of inefficient institutions}

While it is possible to explain how an institution that was once efficient becomes less efficient or even inefficient over time, it appears more difficult to understand why inefficient institutions are generated and spread to begin with. Setterfield (1993) offers three possible explanations to this problem: First, institutions that are substandard or disruptive might result from a hostile selection environment. This could be associated with random processes as suggested in Arthur's (1988) model of path dependence where increasing returns, at some point, lead all agents to choose the same solution over another, even if their original preference was in opposition to this. Second, inefficient institutions might be generated because their creation is easy, following a Pareto process which avoids conflict-laden choices that could involve redistribution. Third, the distinction between efficient and inefficient institutions might not be clear at the outset. Therefore, original choices might turn out to be suboptimal at a later point. In sum, there are many potential sources and cumulative mechanisms of hysteresis that facilitate an enduring persistence of institutions beyond the point in time at which their original formative preconditions might no longer be in place.

\section{Emergent institutional change}

While the discussion of institutional hysteresis focuses on the lasting impact of existing institutions on innovation and technological change, a different perspective may lead us to ask how emergent institutional change occurs under such conditions. This results in a discussion of the role of structure versus agency. 


\subsection{Duality of structure and agency}

A relational perspective emphasizes economic interaction and the contextuality of that interaction within structures of social relations. This, however, does not make it a reductionist micro perspective that is blind to wider societal structures and dynamics. In a way that closely corresponds with structuration theory, a relational perspective aims to theorise social and economic practice beyond the micro-macro divide. Giddens (1984) conceptualises action as a continuous flow of purposeful conduct in the durée of everyday life. Under such conditions, agents are able to monitor and reflect upon their action. The rationality of social action refers to the ability of actors to provide a rationale for their actions. Here, Giddens (1984) distinguishes a discursive and a practical consciousness from which actors draw their ability to find reasons for their actions. But action also has a recursive quality. Through the course of action, agents continuously reproduce the conditions that enable their actions in the first place. This leads to a reflexive dynamic, which Giddens (1984) refers to as the stratification model of action. The model, which has informed the relational approach, points to the limitations of adopting either a pure micro perspective or a pure macro perspective, if done in mutual exclusion.

(i) Limitations of a micro perspective. A central limitation of a micro perspective is that social interaction cannot be fully grasped through an analysis of the acting individuals alone. Unacknowledged conditions and unintended consequences of action, which are unavoidable given the lack of complete information in interaction contexts, constrain any explanations of macro-social phenomena from the perspective of the consciously acting individual (Thompson 1989).

(ii) Limitations of a macro perspective. At the other extreme, structuralist or functionalist approaches are also incomplete in their explanations. The employment of a-priori assumptions 
about the existence of functional mechanisms in macro-social systems leads to an implicit determinism in that social action is explained simply as a product of specific functional constraints or a-priori principles. This perspective tends to reify concepts of social structure as real entities and dismisses the realm of contextuality and purposive social action (Granovetter 1985).

In addressing the conceptual duality of structure and agency, Giddens (1984: 2) suggests a potential solution to the macro-micro dualism: "If interpretative sociologies are founded, as it were, upon an imperialism of the subject, functionalism and structuralism propose an imperialism of the social object. One of my principal ambitions in the formulation of structuration theory is to put an end to each of these empire-building endeavours. The basic domain of study of the social sciences, according to the theory of structuration, is neither the experience of the individual actor, nor the existence of any form of societal totality, but social practices ordered across space and time" (see, also, Thompson 1989). The theorem of the duality of structure and agency resembles the relation between language and speech (Werlen 1995; Barley and Tolbert 1997). While speech is situated in space and time, language is virtual, timeless, and without subject. The same applies to social structure. Though individual agency constitutes social interaction, social structure has only a virtual existence. It is comprised of rules and resources, around which individual agency takes place in a recurrent fashion. In this way, interaction is structured and structure is continuously reproduced. Structure, however, only exists in social interaction (Thompson 1989). Social structure is a virtual order of transformational relations that continuously reproduce social practice (Giddens 1984).

In line with this approach, a relational perspective conceptualises institutions in order to include macro-social structures in the analysis of economic relations. Institutions represent a common social arena for processes of communication, collective learning, and innovation. On the 
one hand, institutions constrain the space for alternative actions (North 1990); on the other hand, they provide the necessary conditions under which continuous interaction is made possible (Hodgson 1988). A relational approach acknowledges that institutions can only become real through the course of social practice and that the interactions between actors are the unit of analysis best suited to understanding the foundations of institutions. Economic action is, in other words, highly contextual in nature; it is situated within material and social relations, as well as institutional contexts. Institutional contexts provide relatively stable social orientations that motivate economic relations. They are recursively reproduced through these relations and transactions.

\subsection{Institutions as mediators}

Related to the context of structuration theory, it can be argued that institutions are critical in resolving the structure-agency dualism and in understanding the linkages between micro and macro levels of economic development (Bathelt and Glückler 2012). From a relational perspective, institutions do not primarily serve to constrain or limit economic action (e.g., North 1991). They possess important opportunity-generating capabilities regarding the interaction within and between firms, as well as across groups of economic agents (Hodgson 1998). In this perspective, institutions are defined not as rules but, following Setterfield (1993: 756), as the "correlated behaviour of agents ... that reoccurs under the same or similar conditions" (Dopfer 1991: 536). Institutions are collective in the sense that they include patterns of behaviour that cannot be traced back to individual agents.

The relational perspective is particularly well-suited to analysing economic institutions in thematic, methodological, and ontological terms (Jessop 2001). Economic institutions can be understood as stabilised forms of social relations that are recursively produced through relational 
action (Bathelt and Glückler 2003). Efficient communication between transaction partners in a particular environment requires the development of a shared context of formal and informal institutions. This encourages specialised users and producers to discuss and solve problems. Such a framework does not, however, exist spontaneously. It develops over time and requires the joint experiences and interactions of agents in relation to one another. Institutions might involve a set of shared understandings of best-practice technologies, key concepts, signs, and expectations, or include tacit agreements about the solutions and practices that are suboptimal or do not work. In an economic context, the development of institutions can be strongly guided along the lines of socalled knowing communities (Amin and Cohendet 2004; Cohendet, Héraud, and Llerena 2013), such as epistemic communities (Knorr Cetina 1999) and communities of practice (Brown and Duguid 1991; Wenger 1998). ${ }^{11}$

From a territorial perspective, our previous arguments suggest that, although average patterns of interaction may be identifiable, specific contexts lead to some variation resulting in a situation of institutional variety over space, rather than homogeneity. As a result, we may be able to identify different patterns of employing technologies at the firm level, as demonstrated by Orlikowski (2000). Regardless of some 'natural' variation, we can expect more fundamental differences to exist between different countries, as the various rules, norms, conventions, habits, and technology attitudes that affect economic practices - and, thus, institutions - are often shaped by the settings negotiated at the level of the national state (Lundvall and Maskell 2000; Hall and

\footnotetext{
${ }^{11}$ Here, we need to distinguish between institutions and communities in that institutions relate to the practice level, while communities refer to the agent level. Communities are agents that are bound together by shared practices and, as such, build on and develop around a joint set of institutions. Regular community meetings and interaction, in turn, may give rise to the development of new institutions (Bathelt and Glückler 2012). The analysis of these communities is important in order to gain insights as to how institutions change over time and how institutional practices can differ from place to place (Wenger 1998).
} 
Soskice 2001). Or, as Coriat and Dosi (1998: 108) suggest, "specific problem-solving competencies deeply affect the ability of both individual firms and whole countries to generate and adopt new technologies." Even in the context of increasing economic globalisation, the national state still has an important impact on the basic conditions under which firms operate. At the same time, globalisation increasingly shapes processes of institutionalisation and challenges the boundaries of the national state, creating another dualism that institutions help mediate. In a similar way, institutions are also significant in the context of regional production (Asheim and Isaksen 2002; Amin 1999) in that they enable inter-firm collaboration by translating and adjusting national conditions into regional specificities.

Overall, this suggests that different layers of institutions exist that can support or may work against one another. ${ }^{12}$ The relations between 'community' (e.g., the regional or industrial context) and 'society' (i.e., the national context), for instance, are decisive in understanding why some places grow faster than others (Rodríguez-Pose and Storper 2006; Storper 2004; Farole, Rodríguez-Pose, and Storper 2010). In addition to these levels, Clark, Tracey, and Lawton-Smith (2001) emphasize the context of 'family' inheritance for regional development (i.e., the firm context). These endowments and inheritances include institutions at different scales that support interactive learning. Family inheritance refers to the regional firms' accumulated capabilities and describes the overall ability of all firms in a region to learn individually. In contrast, community inheritance encompasses the overall capacity for interaction and learning between firms in a specific region (or, alternatively, between firms in an industry), while society endowments relate to the overall societal opportunities and restrictions for interaction. In the short run, these inheritances are more-or-less fixed and cannot be changed by individual actors. In the longer run,

\footnotetext{
${ }^{12}$ See Bathelt (2006: 229f.).
} 
however, territorial policies can influence processes of economic development by (re)defining institutional conditions at different levels. They may thus create a set of nested scales that are neither hierarchical nor deterministic (Swyngedouw 1997). Economic action and interaction are mediated through and between these scales because activities take place simultaneously at various levels, and thus have multi-scalar influences (Bunnell and Coe 2001).

The above arguments suggest that a relational perspective does not rule out macro-theoretical considerations because economic agency is, of course, not independent from the conditions of the capitalist system. Institutions mediate between both the micro and macro levels (Jessop 2001). They create a connection between the wider societal structures and economic agency. On a different level, this may help elucidate the relationship between the specific and the general, or between the local and the global (e.g., Clark 2005). ${ }^{13}$ On the one hand, institutions shape economic practices and should, thus, be studied at the level of the economic actor (Hodgson 1998). On the other hand, the institutional context motivates on-going relations between agents and encourages patterns of reproduction. This, in turn, influences the institutional conditions under which economic action takes place. Overall, a reflexive process of economic interaction and institution-building can be conceptualised (see Hudson 2004). This process involves influences from macro structures, such as the capitalist system, that are transferred to the individual level through institutions in a process of downward causation. At the same time, there is also a process of upward causation (Hodgson 2003), which describes how micro practices are translated into broader institutional arrangements that affect the macro level.

\footnotetext{
${ }^{13}$ It should be emphasized that we do not attempt to establish the usual 'false dualisms' (Sayer 1985) of the form micro $=$ specific $=$ local vs. macro $=$ general $=$ global. Neither do we restrict agency to the local and structure to the global scale (see, also, Ettlinger 2011).
} 
The processes of upward and downward causation lead us to employ a dynamic perspective to understand how institutions change over time. While institutional change has often been viewed as a top-down process following, for instance, the introduction of new rules or government policies as in the state-centred approach of Skocpol (1979) (see, Hooghe and Marks 2003), other work suggests that institutions are also shaped through bottom-up processes. According to Hall and Thelen (2009: 17): “[c]hanges in rules often follow the accumulation of 'deviant' behaviour". Thelen's (2004) historical perspective on institutional conversion in the German political economy, for example, demonstrates how institutions come to be used in ways that differ from what they were originally built for (Streeck and Thelen 2005). Hall and Thelen (2009) provide several illustrative examples of such 'shifts from below', where incremental changes in patterns of economic interaction generate new demands regarding the general institutional field. In a similar vein, Tsai (2010) shows how adaptive informal institutions can trigger changes in formal structures. Using the case of reforms in contemporary China, Tsai (2007) demonstrates that such bottom-up processes of institutional change can occur even in non-democratic authoritarian states.

Giddens (1984) has described these processes of upward and downward causation as reflexive relationships between structure and agency. This does not mean that structure determines agency and vice versa, creating a vicious cycle without any explanatory significance. Rather, interdependence between institutions and agency results in progressive development, where institutions mediate between individuals and wider societal structures. ${ }^{14}$ Yet, as Murdoch (1995) suggests, there is a danger of constructing macro explanations to interpret micro-scale processes without sufficient empirical evidence. It is generally problematic to simply transfer findings from one level of aggregation to another. Therefore, interpretations of macro-scale trends in economic

\footnotetext{
${ }^{14}$ See, also, Jessop's (2001) structural-relational approach.
} 
and societal development should be based on, at least, some micro-scale evidence related to practices of economic action and the social relations through which these practices are channelled (e.g., Yeung 2005). Although this section argues that institutions connect different scales and accommodate dynamic changes by mediating between structure and agency, shifts in institutions are neither automatic nor frictionless processes. This is demonstrated in the next section on institutional entrepreneurship, which also links back to the processes of institutional hysteresis discussed before.

\section{Institutional entrepreneurship}

\subsection{Solving the paradox of embedded action}

Given their relative inertia and stability, institutions cannot easily be changed, designed, or implemented by individual purposive action. Theoretically, the idea of purposive institutional design leads to the paradox of embedded action (Powell and DiMaggio 1991): How is institutional change possible if the actors' intentions, actions, and rationalities are conditioned by the institutions that they wish to change (Leca and Naccache 2006)? This paradox can be resolved through social action that is fundamentally reflexive and contextual in nature. Social action cannot be understood as the execution of institutional scripts but unfolds as reflexive interaction in specific spatio-temporal contexts (Emirbayer and Mische 1998). When actors associate particular interests and individual advantages with potentially new institutions, they rather aim to accelerate and support their development and adoption. Institutional entrepreneurship describes the actions taken by organised actors with the intention to change existing and to establish new institutions (Maguire, Hardy, and Lawrence 2004; Garud, Hardy, and Maguire 2007). Institutional entrepreneurs are interested in enforcing change in existing 
institutional settings. Since existing institutions provide benefits to many actors, institutional entrepreneurs need to mobilise resources (DiMaggio 1988) and develop particular capabilities (Perkmann and Spicer 2007) in order to promote legitimacy for change and to convince others to adopt new practices. From this, it is possible that new patterns of mutual expectations emerge based on continuous flows of interaction (e.g., new inter-firm cooperation practices). Such socalled proto-institutions (Lawrence, Hardy, and Phillips 2002) may succeed and, over time, consolidate and develop into widely accepted and adopted institutions.

The historical shift from industrial whale hunting to whale watching is an illustrative example how a new institutional field can emerge through the interplay between macro-societal structures and local contextual interaction at the micro level (Bathelt and Glückler 2012). From the end of the 1980s onward, the demand for whale watching tours that originally started in the 1950s rose tremendously and, today, many coastal regions in the world offer such tours (WWF 2004). Whale watching generated an estimated 13,000 jobs globally by the mid 2000s (Hoyt and Iñíguez 2008). The case of whale watching is a good example of institutional entrepreneurship that required overcoming existing institutions and enforcing new ones.

In their study of Victoria, Canada, Lawrence and Phillips (2004) reconstructed the evolution of this new field. On the one hand, the societal discourse was important that had moved from a connotation of the whale as a 'hunting good' to one as a 'natural heritage' that needs to be protected - and, further, to one of an 'endearing specialty' within ecological diversity. Parallel, the perception of the whale in popular culture changed from the dangerous beast 'Moby Dick' to the endangered 'Free Willy'. On the other hand, these changing attitudes were accompanied by the construction of a new local institutional field - i.e., that of whale watching - at the micro level (Lawrence and Phillips 2004). Pioneers responded to opportunities to launch whale watching tours; early followers imitated the pioneers; the new firms collaborated with research 
organisations to establish a system of whale spotting; and, finally, growth and crowding effects required the firms to build business associations, to implement sets of new rules and conventions to respect environmental laws, and to cope with competition. These rules, in turn, became the new foundations of everyday practice. As a consequence of the pro-active design of new organisations (business associations) and rules, the stakeholders of this institutional field developed stable patterns of mutual interactions to service tourist demand, to coordinate competition between tour operators, and to meet governmental and public expectations with respect to environmental protection. The example of whale watching demonstrates how institutional entrepreneurs managed to structure an emerging institutional field and how they enforced the legitimacy of new institutions as novel patterns of stabilised interactions (Lawrence and Phillips 2004). While this case may not be directly related to technological change, Kodak's case of strong institutional entrepreneurship that transformed photography from a highly specialised activity to one that became an integral part of everyday life (Munir and Phillips 2005) clearly shaped the development of a broad array of technologies and economic development (see, also, Greenwood and Suddaby 2006). Institutional entrepreneurship also plays an important role in the social construction of markets, as discussed in the following section.

\subsection{A geography of market- making}

In situations of institutional hysteresis, such as those discussed above, it is a challenging task to overcome ossification and negative lock-in, and develop new institutional arrangements, best practices, and/or standards. Addressing such non-routine processes requires collective action - a process that is itself grounded in and shaped by institutional settings. This can be illustrated in the context of markets and market institutions. While it appears obvious that institutions affect transactions within firms (hierarchies) and within networks (Coase 1937), this is not 
automatically clear in the case of market transactions - at least from the perspective of neoclassical economics. Markets have traditionally been viewed as idealised settings, in which atomistic agents with perfect knowledge buy and sell products in order to maximise their individual benefits. Such markets are governed by price mechanisms and exchange processes that do not require social interactions. However, as Hodgson (1988) points out, markets are not free of institutions. Institutions shape the perceptions and preferences of economic agents and, thus, have an important impact on interaction patterns in market transactions (Bathelt and Glückler 2011). In fact, it is a virtual impossibility to explain the existence of markets without acknowledging the role of institutions. It is difficult, for instance, to understand market transactions at an auction without emphasising the role of the auctioneer. Deviating from classical explanations, markets are also characterised by regulations, such as price norms, which support certain types of behaviour - and not others (Hodgson 1988). How this operates, can be understood by analysing how markets are constructed in relational ways, as suggested in actor-network theory (Callon 1998).

The rules and regularities of markets are constrained - both in time and space. Since each transaction is accompanied by different degrees of risk, uncertainty, and valuation problems both on the supply and demand side - markets have to be viewed as contextual social constructs that are specific in time and space for each product or service (Callon 1998). How do market regularities emerge under such circumstances? From an evolutionary and institutional perspective, markets are composites of price mechanisms and sets of specific rules, conventions, and practices that coordinate expectations and compliances between supply and demand (Granovetter 1993; Hodgson 1999; Ménard 1995). These rules are made, first, by vendors and suppliers seeking to obtain new clients for their products (Loasby 2000), and, second, by regulating authorities and similar organisations that enforce compliance to prevent opportunistic behaviour and market 
failure (Boyer 1997). The advantage of such settings is that trade can proceed continuously under a set of established rules of exchange, instead of having to be constantly renegotiated for each transaction. This leads to substantial cost savings.

Once an institutional arrangement made by a vendor is acceptable for customers, the level of mutual uncertainty decreases such that scale economies can become effective. As a particular set of rules and conventions becomes increasingly accepted over time and used by customers, the unit cost of 'making' the market declines. Although businesses that fail to create appropriate market arrangements might disappear, those that are successful benefit from large demand and are being imitated by others (Loasby 2000). Transactions in spatially and temporally defined, organised markets are more efficient than ad-hoc transactions, which require full negotiation of all terms of the exchange (Hodgson 1988; Sayer 1995).

The challenges of suppliers and supporting actors, such as regulating authorities, business associations, and consultants, are thus to observe, explore, and develop appropriate rules and conventions of exchange that will be accepted by the customers. Customers benefit from marketmaking because explicit rules of exchange reduce uncertainty regarding their suppliers, even though market institutions, in terms of stabilised interaction patterns, might still deviate from these rules. There are numerous arrangements that suppliers can employ to reduce customer uncertainty. Warranties, sample products, subsequent improvement, and performance-based fees are incentives that suppliers and legislators may offer to make markets attractive to customers. They become the basis for stable transaction patterns (Bathelt and Glückler 2012). Those mechanisms that prove to be useful are later likely copied and transferred to other service and product markets and may thus spread throughout the economy. Additionally, emergent markets are embedded in broader sets of institutional arrangements that also include authoritative resources, such as sanctions, to enforce compliance (Boyer 1997). 
The abstract model of the neoclassical market is more accurately described as a theory of exchange, rather than one of the market (Beckert 2009). It neither has a spatial nor a temporal dimension. Geographical expressions of the economy are not possible without transportation and transaction costs and without situated, contextual institutional arrangements regarding the terms of trade. It is exactly this temporal and spatial contextuality that transforms a single abstract market into diverse real markets. And because of this, economic action is transformed into relational action in spatial perspective (Bathelt and Glückler 2011). As a consequence, increasing attention has been paid in recent years to the cultural foundations of economic interaction, especially focusing on the anthropology of markets (Callon 1998), convention theory (Boltanski and Thévenot 2006), and the development and negotiations of market rules and conventions (e.g., Swain 2006; Hall 2008; Berndt and Boeckler 2009). Markets are constructed in a relational manner. They emerge from a complex interplay of macro-institutional legislation and politics, societal institutions, and the everyday negotiations and experimentations between suppliers, customers, and other parties at the micro level. Overall, relational influences do not only impact the specificity and contextuality of markets in the present, but equally shape continuous reproduction over time.

\section{Conclusions and future research challenges}

This paper presents a critical review and suggestions of how to conceptualise institutions in the context of economic geography and technological change. It understands institutions through a broad established social science perspective and, as such, differs from literature that implicitly or explicitly treats institutions as if they were a 'black box' - employed to explain otherwise unexplainable economic phenomena. In contrast, we present an explicit understanding of institutions that deviates from defining them as simple regularities, rules, or organisations 
(governments). We view institutions as correlated and relatively stable social interaction between economic agents that develop upon rules and regulations in rather contingent ways. Although institutions may represent the intentions inherent in rules, they unfold in practices that deviate to a greater or lesser extent, or even disregard them. Therefore, rules are fundamentally different from institutions - they are 'not yet institutions'.

Drawing on Giddens' (1984) structuration theory, we elaborate a conception of institutions that acknowledges both upward and downward causation processes. This allows us to analyse how institutions simultaneously shape and are shaped by processes of economic interaction. This framework opens up new possibilities to integrate micro and macro phenomena in analysing economic action and technological change in spatial perspective, while, at the same time, highlighting the importance of micro-level research in the study of economic processes. The framework helps to understand how markets are made in a place- and time-specific fashion, how they operate, and how they adapt to changes over time. Nonetheless, there are some crucial research challenges, both theoretically and empirically, in unravelling the geographically diverse dynamics and structures of institutionalisation of the economy and technological change.

One major methodological challenge is related to studying the emergence, production, and change of institutions empirically. The duality of structure and agency implies that institutions cannot be measured by obvious or easily identifiable indicators, but need to be analytically extracted from social practice. This is because they are not identical with rules and regulations but develop from repeated action that is related to them - they are the consequences related to such rules, not the rules themselves. Barley and Tolbert (1997) offer an original methodological approach to study institutions and processes of institutionalisation. Accordingly, institutions can only be discovered in inter-situational repeated action. This can be best accomplished in periods of institutional change and requires longitudinal and/or cross-sectional observations. Additionally, 
the empirical research design needs to follow a diachronic model that analyses the recursive processes of institutionalisation and action sequentially. The processes of encoding and enacting institutional scripts into action as well as the processes of replicating, revising, and objectifying these scripts through action are thus best studied in a sequential, longitudinal way (Barley and Tolbert 1997). This can be conducted through in-depth interviews or observation techniques, as well as other methods that are able to record process information.

Another challenge is the relation between institutions (respectively their underlying rules and regulations) and economic outcomes. We are constantly confronted with questions regarding the appropriate or best level of institutional support for regional economic development and innovation: How much institutional support is helpful or positive and under which conditions can this create problems? Such questions are not trivial - even conceptually; they are difficult to answer, as van Waarden's (2001) fascinating study about the relations between legal institutions and the innovativeness of national economies demonstrates. In line with institutional theory, van Waarden (2001) assumes that institutions are an important means to reduce uncertainty. Hence, when institutional fields, such as legislation, absorb uncertainty, it should be more likely for citizens to take the risk of innovation. The empirical assessment of two national legal systems suggests that regulation-based legislation in the Netherlands implies less uncertainty than mitigation-based legislation in the United States. Accordingly, Dutch entrepreneurs should be expected to be more risk-taking and innovative than U.S. entrepreneurs. However, the empirical findings reveal the opposite, raising the crucial question as to whether legislations are really a remedy for or rather a mirror of the risk-aversion of national cultures.

This example illustrates that, despite the plausibility of arguments, the empirical state of knowledge about institutions, institutional change, and its interrelations with economic, social, and technological phenomena is still in its infancy. In this paper, we have aimed at sensitizing the 
geographical debate to both (i) the empirical contingencies between rules and 'institutions-inpractice' and (ii) the theoretical confusion which results from the diverse and often implicit understandings of the term 'institution' and from the ways how these understandings sometimes alternate. We have elaborated a novel understanding of institutions and used several examples to argue that rules and regulations are only contingent conditions for the emergence and transformation of socio-economic institutions in spatial perspective. Because of such fundamental contingency, the effects of regulations on economic relations - and economic outcomes - can be unintended, unforeseeable, and even counterproductive. Regional and innovation policies that are limited to causal models where economic outcomes are immediate effects of rules (incentives or sanctions) will necessarily raise expectations that cannot be fulfilled or be ill-fated altogether. And conceptual accounts that equate institutions with governments and regulations will fail to understand the contingency-gap between codified or uncodified rules and economic practices. While a detailed account about specific policy implications would go beyond the scope of this paper, our arguments emphasize the need for regional and innovation policy to be reflective, responsive, and adaptable to the specific local and non-local contextuality of economic action and the underlying institutions, in order to support expected outcomes.

Clearly, at this point, we cannot give final answers to many related questions. But the paper aims to raise awareness for the importance of these questions and the need to deal with them conceptually and empirically - issues that have been neglected for much too long in main stream economic geography. We attempt in this paper to broaden our perspective of relational action beyond individual or collective agents and their direct transaction partners to include wider societal and economic structures and developments. To insist on applying an explicit and consistent understanding of institutions in economic (and, in fact, human) geography will provide us with the opportunity to 'translate' the findings of other studies that apply different 
understandings into comprehensive concepts and theories of the relations between technological and market change, relational action, and institutional change.

\section{Bibliography}

Allen, J. 2003. Lost Geographies of Power. Malden, MA, Oxford: Blackwell.

Amin, A. and N. Thrift. 1992. Neo-Marshallian nodes in global networks. International Journal of Urban and Regional Research 16:571-587.

Amin, A. 1999. An institutionalist perspective on regional economic development. International Journal of Urban and Regional Research 23:365-378.

Amin, A. and P. Cohendet. 2004. Architectures of Knowledge: Firms, Capabilities, and Communities. Oxford, New York: Oxford University Press.

Archibugi, D.; J. Howells; and J. Michie. 1999. Innovation systems and policy in a global economy. In Innovation Policy in a Global Economy, ed. D. Archibugi; J. Howells; and J. Michie, 1-17. Cambridge: Cambridge University Press.

Arthur, W.B. 1988. Competing technologies: An overview. In Technical Change and Economic Theory, ed. G. Dosi; C. Freeman; R.R. Nelson; G. Silverberg; and L. Soete, 590-607. London, New York: Pinter Publishers.

Asheim, B.T. and A. Isaksen. 2002. Regional innovation systems: The integration of local 'sticky' and global ‘ubiquitous' knowledge. Journal of Technology Transfer 27:77-86.

Barley, S.R. and P.S. Tolbert. 1997. Institutionalization and structuration: Studying the links between action and institution. Organization Studies 18:93-117.

Bathelt, H. 2006. Geographies of production: Growth regimes in spatial perspective 3 - Toward a relational view of economic action and policy. Progress in Human Geography 30:223236.

Bathelt, H. and J. Glückler. 2003. Toward a relational economic geography. Journal of Economic Geography 3:117-144. 
- 2011. The Relational Economy. Geographies of Knowing and Learning. Oxford: Oxford University Press.

. 2012. Wirtschaftsgeographie. Ökonomische Beziehungen in räumlicher Perspektive (Economic Geography. Economic Relations in Spatial Perspective). Stuttgart: Ulmer, UTB.

Beckert, J. 2009. The social order of markets. Theory and Society 38:245-269.

Berndt, C. and M. Boeckler. 2009. Geographies of circulation and exchange: Constructions of markets. Progress in Human Geography 33:535-551.

Boltanski, L. and L. Thévenot. 2006. De la Justification. Les économies de la grandeur. Paris: Gallimard.

Boschma, R. and K. Frenken. 2009. Some notes on institutions in evolutionary economic geography. Economic Geography 85:151-158.

Boyer, R. 1997. The variety and unequal performance of really existing markets: Farewell to Doctor Pangloss? In Contemporary Capitalism. The Embeddedness of Institutions, ed. J.R. Hollingsworth and R. Boyer, 55-93. Cambridge, New York: Cambridge University Press.

Brown, J.S. and P. Duguid. 1991. Organizational learning and communities-of-practice: Toward a unified view of working, learning, and innovating. Organization Science 2:40-57.

Bunnell, T.G. and N.M. Coe. 2001. Spaces and scales of innovation. Progress in Human Geography 25:569-589.

Callon, M. 1998. Introduction: The embeddedness of economic markets in economics. In The Laws of the Markets, ed. M. Callon, 1-57. Oxford: Blackwell.

Clark, G.L. 2005. Beyond close dialogue: Economic geography as if it matters. In Economic Geography Research Group Working Papers WPG 05-04. Oxford: School of Geography and the Environment, Oxford University.

Clark, G.L.; P. Tracey; and H. Lawton Smith. 2001. Agents, endowments, and path-dependence: A model of multi-jurisdictional regional development. Geographische Zeitschrift 89:166181.

Coase, R.H. 1937. The nature of the firm. Economica 4:386-405. 
Cohendet, P.; J.-A. Héraud; and P. Llerena. 2013. A microeconomic approach of the dynamics of creation. In Knowledge and Space - Vol. 5: Knowledge and Economy, ed. P. Meusburger; J. Glückler; and M. el Meskioui, 43-59. Berlin, Heidelberg: Springer.

Coriat, B. and G. Dosi. 1998. Learning how to govern and learning how to solve problems: On the co-evolution of competences, conflicts and organizational routines. In The Dynamic Firm: The Role of Technology, Strategy, Organization, and Regions, ed. A.D.J. Chandler; P. Hagström; and Ö. Sölvell, 103-133. New York: Oxford University Press.

DiMaggio, P.J. 1988. Interest and agency in institutional theory. In Research on Institutional Patterns and Organizations: Culture and Environment, ed. L. Zucker, 3-22. Cambridge, MA: Ballinger.

Dopfer, K. 1991. Toward a theory of economic institutions: Synergy and path dependency. Journal of Economic Issues 25:535-550.

Edquist, C. and B. Johnson. 1997. Institutions and organizations in systems of innovation. In Systems of Innovation: Technologies, Institutions and Organizations, ed. C. Edquist, 4163. London: Pinter.

Emirbayer, M. and A. Mische. 1998. What is agency? The American Journal of Sociology 103:962-1023.

Esser, H. 2000. Soziologie. Spezielle Grundlagen. Band 5: Institutionen (Sociology. Specific Foundations. Volume 5: Institutions). Frankfurt am Main, New York: Campus.

Ettlinger, N. 2003. Cultural economic geography and a relational and microspace approach to trusts, rationalities, networks, and change in collaborative workplaces. Journal of Economic Geography 3:145-172.

- 2004. Toward a critical theory of untidy geographies: The spatiality of emotions in consumption and production. Feminist Economies 10(3):21-54.

-2011. Governmentality as epistemology. Annals of the Association of American Geographers 101:537-560.

Farole, T.; A. Rodríguez-Pose; and M. Storper. 2010. Human geography and the institutions that underlie economic growth. Progress in Human Geography 35:58-80. 
Farrell, H. and J. Knight. 2003. Trust, institutions, and institutional change: Industrial districts and the social capital hypothesis. Politics \& Society 31:537-566.

Feldman, M.S. and B.T. Pentland. 2003. Reconceptualizing organizational routines as a source of flexibility and change. Administrative Science Quarterly 48:94-118.

Foucault, M. 1980a. Truth and power. In Power/knowledge: Selected interviews and other writings 1972-1977. Michel Foucault, ed. C. Gordon, 109-133. New York: Pantheon.

-1980b. Power and strategies. In Power/knowledge: Selected interviews and other writings 1972-1977. Michel Foucault, ed. C. Gordon, 134-145. New York: Pantheon.

- 2000. Questions of method. In Michel Foucault - Power. Essential Works of Foucault 1954-1984, ed. J.D. Faubion, 223-238. New York: The New Press.

Frankel, M. 1955. Obsolescence and technological change in a maturing economy. American Economic Review 45:296-319.

Garud, R.; C. Hardy; and S. Maguire. 2007. Institutional entrepreneurship as embedded agency: An introduction to the special issue. Organization Studies 28:957-969.

Gertler, M.S. 2004. Manufacturing Culture: The Institutional Geography of Industrial Practice. Oxford, New York: Oxford University Press.

- 2010. Rules of the game: The place of institutions in regional economic change. Regional Studies 44:1-15.

Giddens, A. 1984. The Constitution of Society. Outline of the Theory of Structuration. Cambridge: Polity Press.

Glückler, J. 2005. Making embeddedness work: Social practice institutions in foreign consulting markets. Environment and Planning A 37:1727-1750.

Gordon, C. 2000. Introduction. In Michel Foucault - Power. Essential Works of Foucault 19541984, ed. J.D. Faubion, xi-xli. New York: The New Press.

Grabher, G. 1993. Rediscovering the social in the economies of interfirm relations. In The Embedded Firm. On the Socioeconomics of Industrial Networks, ed. G. Grabher, 1-31. London, New York: Routledge. 
Grabher, G. and O. Ibert. 2013. Distance as asset? Knowledge collaboration in hybrid virtual communities. Journal of Economic Geography 13. doi: 10.1093/jeg/lbt014.

Granovetter, M. 1985. Economic action and economic structure: The problem of embeddedness. American Journal of Sociology 91:481-510.

1993. The nature of economic relationships. In Explorations in Economic Sociology, ed. R. Swedberg, 3-41. New York: Russell Sage.

Greenwood, R. and R. Suddaby. 2006. Institutional entrepreneurship in mature fields: The big five accounting firms. Academy of Management Journal 49:27-48.

Hall, P.A. and D. Soskice. 2001. An introduction to varieties of capitalism. In Varieties of Capitalism: The Institutional Foundations of Comparative Advantage, ed. P.A. Hall and D. Soskice, 1-68. Oxford, New York: Oxford University Press.

Hall, P.A. and K. Thelen. 2009. Institutional change in varieties of capitalism. Socio-Economic Review 7:7-34.

Hall, S. 2008. Geographies of business education: MBA programmes, reflexive business schools and the cultural circuit of capital. Transactions of the Institute of British Geographers 33:27-41.

Hargadon, A.B. and J.Y. Douglas. 2001. When innovations meet institutions: Edison and the design of electric light. Administrative Science Quarterly 46:476-501.

Hartfiel, G. and K.-H. Hillmann. 1982. Wörterbuch der Soziologie. Stuttgart: Kröner.

Hassink, R. and D.-H. Shin. 2005. Guest editorial: The restructuring of old industrial areas in Europe and Asia. Environment and Planning A 37:571-580.

Hodgson, G.M. 1988. Economics and Institutions: A Manifesto for a Modern Institutional Economics. Cambridge: Polity. 1998. The approach of institutional economics. Journal of Economic Literature 36:166192.

1999. Economics \& Utopia. Why the Learning Economy is not the End of History. London, New York: Routledge. 
- 2003. The hidden persuaders: Institutions and individuals in economic theory. Cambridge Journal of Economics 27:159-175.

Hooghe, L. and G. Marks. 2003. Unraveling the central state, but how? Types of multi-level governance. American Political Science Review 97:233-243.

Hoyt, E. and M. Iñíguez. 2008. The State of Whale Watching in Latin America. WDCS, Chippenham; IFAW, Yarmouth Port; and Global Ocean, London.

Hudson, R. 2004. Conceptualizing economies and their geographies: Spaces, flows and circuits. Progress in Human Geography 28:447-471.

Jessop, B. 2001. Institutional re(turns) and the strategic-relational approach. Environment and Planning A 33:1213-1235.

Jones, A. and J. Murphy. 2010. Theorizing practice in economic geography: Foundations, challenges, possibilities. Progress in Human Geography 35:366-392.

Katzenstein, P.J. 1987. Policy and Politics in West Germany: The Growth of a Semisovereign State. Philadelphia: Temple University Press.

Knorr Cetina, K. 1999. Epistemic Cultures: How the Sciences Make Sense. Chicago: Chicago University Press.

Latour, B. 1986. The powers of association. In Power, Action and Belief: A New Sociology of Knowledge?, ed. J. Law, 264-280. London: Routledge \& Kegan Paul.

Lawrence, T.B.; C. Hardy; and N. Phillips. 2002. Institutional effects of interorganisational collaboration: The emergence of proto-institutions. Academy of Management Journal 45:281-290.

Lawrence, T.B. and N. Phillips. 2004. From Moby Dick to Free Willy: macro-cultural discourse and institutional entrepreneurship in emerging institutional fields. Organization 11:689711.

Lawson, C. and E. Lorenz. 1999. Collective learning, tacit knowledge and regional innovative capacity. Regional Studies 33:305-317.

Leca, B. and P. Naccache. 2006. A critical realist approach to institutional entrepreneurship. Organization 13:627-651. 
Loasby, B.J. 2000. Market institutions and economic evolution. Journal of Evolutionary Economics 10:297-309.

Lorenz, E. 1999. Trust, contract and economic cooperation. Cambridge Journal of Economics 23:301-315.

Luhmann, N. 1984. Soziale Systeme: Grundriss einer allgemeinen Theorie (Social Systems: Foundations of a General Theory). Frankfurt/Main: Suhrkamp.

Lundvall, B.-Å. 1992. User-producer relationships, national systems of innovation and internationalisation. In National Systems of Innovation: Towards a Theory of Innovation and Interactive Learning, ed. B.-Å. Lundvall, 45-67. London: Pinter, 45-67.

Lundvall, B.-Å. and P. Maskell. 2000. Nation states and economic development: From national systems of production to national systems of knowledge creation and learning. In The Oxford Handbook of Economic Geography, ed. G.L. Clark; M.P. Feldman; and M.S. Gertler, 353-372. Oxford: Oxford University Press.

Maguire, S.; C. Hardy; and T.B. Lawrence. 2004. Institutional entrepreneurship in emerging fields: HIV/AIDS treatment advocacy in Canada. Academy of Management Journal 47:657-679.

Marquis, C. 2003. The pressure of the past: Network imprinting in intercorporate communities. Administrative Science Quarterly 48:655-689.

Martin, R. and P. Sunley. 2006. Path dependence and regional economic evolution. Journal of Economic Geography 6:395-437.

Maskell, P. 2001. The firm in economic geography. Economic Geography 77:329-344.

Massey, D. 2004. Geographies of responsibility. Geografiska Annaler 86B:5-18.

Ménard, C. 1995. Markets as institutions vs. organizations as markets? Disentangling some fundamental concepts. Journal of Economic Behavior and Organization 28:161-182.

Munir, K.A. and N. Phillips. 2005. The birth of the 'Kodak Moment': Institutional entrepreneurship and the adoption of new technologies. Organization Studies 26:16651687. 
Murdoch, J. 1995. Actor-networks and the evolution of economic forms: Combining description and explanation in theories of regulation, flexible specialization, and networks. Environment and Planning A 27:731-757.

Nelson, R.R. ed. 1993. National Innovation Systems: A Comparative Analysis. Oxford: Oxford University Press.

Nelson, R.R. 1995. Evolutionary theorizing about economic change. Journal of Economic Literature 23:48-90.

Nelson, R. and K. Nelson. 2002. Technology, institutions, and innovation systems. Research Policy 31:265-272.

Nelson, R.R. and S.G. Winter. 1982. An Evolutionary Theory of Economic Change. Cambridge, MA: Harvard University Press.

North, D.C. 1990. Institutions, Institutional Change and Economic Performance. Cambridge: Cambridge University Press.

North, D.C. 1991. Institutions. The Journal of Economic Perspectives 5:97-112.

Oinas, P. 2006. The many boundaries of the firm. In Understanding the Firm: Spatial and Organizational Dimensions, ed. M. Taylor and P. Oinas, 35-60. Oxford: Oxford University Press.

Orlikowski, W.J. 2000. Using technology and constituting structures: A practices lens for studying technology in organizations. Organization Science 11:404-428.

Perkmann, M. and A. Spicer. 2007. 'Healing the scars of history': Projects, skills and field strategies in institutional entrepreneurship. Organization Studies 28:1101-1122.

Powell, W.W. and P. DiMaggio. 1991. The New Institutionalism in Organizational Analysis. Chicago, London: The University of Chicago Press.

Rodríguez-Pose, A. and M. Storper. 2006. Better rules or stronger communities? On the social foundations of institutional change and its economic effects. Economic Geography 82:125.

Sayer, A. 1985. The difference that space makes. In Social Relations and Spatial Structures, ed. D. Gregory and J. Urry, 49-66. Basingstoke: Macmillan. 
— 1995. Radical Political Economy. London, New York: Sage.

—. 2001. For a critical cultural political economy. Antipode 33:687-708.

Scott, A.J. 2004. A perspective of economic geography. Journal of Economic Geography 4:479499.

Setterfield, M. 1993. A model of institutional hysteresis. Journal of Economic Issues 27:755-774.

Skocpol, T. 1979. States and Social Revolutions: A Comparative Analysis of France, Russia and China. Cambridge: Cambridge University Press.

Stinchcombe, A.L. 1965. Social structure and organization. In Handbook of Organizations, ed. J.G. March, 142-193. Chicago: Rad McNelly.

Storper, M. 2004. Institutions, Incentives and Communication in Economic Geography. Wiesbaden Franz Steiner Verlag.

Streeck, W. and K. Thelen. 2005. Introduction. In Beyond Continuity: Institutional Change in Advanced Political Economies, ed. W. Streeck and K. Thelen, 1-39. Oxford: Oxford University Press.

Swain, A. 2006. Soft capitalism and a hard industry: Virtualism, the 'transition industry' and the restructuring of the Ukrainian coal industry. Transactions of the Institute of British Geographers NS 31:208-223.

Swyngedouw, E. 1997. Neither global nor local: 'Glocalization' and the politics of scale. In Spaces of Globalization: Reasserting the Power of the Local, ed. K.R. Cox, 137-166. New York, London: Guilford.

Taylor, M.J. 2004. The firm as a connected, temporary coalition. In SPACES, Vol. 2, 2004-05. Marburg: Faculty of Geography, Philipps-University of Marburg.

Thelen, K. 2004. How Institutions Evolve: The Political Economy of Skills in Germany, Britain, the United States and Japan. New York: Cambridge University Press.

Thompson, J.B. 1989. The theory of structuration. In Social Theory of Modern Societies: Anthony Giddens and his Critics, ed. D. Held and J.B. Thompson, 56-76. Cambridge. 
Tsai, K.S. 2007. Capitalism Without Democracy: The Private Sector in Contemporary China. Ithaca: Cornell University Press.

Tsai, K.S. 2010. The Great Socialist Transformation: Capitalism Without Democracy in China. Paper presented at the University of Toronto, Toronto: Munk Centre for International Studies.

Uzzi, B. 1996. The sources and consequences of embeddedness for the economic performance of organizations: The network effect. American Sociological Review 61:674-698. 1997. Social structure and competition in interfirm networks: The paradox of embeddedness. Administrative Science Quarterly 42:35-67.

van Waarden, F. 2001. Institutions and innovation: The legal environment of innovating firms. Organization Studies 22:765-795.

Wenger, E.C. 1998. Communities of Practice: Learning, Meaning, and Identity. Cambridge: Cambridge University Press.

Wenger, E.C. and W.M. Snyder. 2000. Communities of practice: The organizational frontier. Harvard Business Review 78: 139-145.

Werlen, B. 1995. Sozialgeographie alltäglicher Regionalisierungen. Band 1: Zur Ontologie von Gesellschaft und Raum. Stuttgart: Steiner.

WWF. 2004. Walbeobachtung - Whale Watching. Frankfurt am Main: World Wide Fund For Nature Deutschland.

Yeung, H.W.-c. 2005. Rethinking relational economic geography. Transactions of the Institute of British Geographers 30:37-51. 